\title{
Cell performance of strontium ruthenium oxide cathode/ Gd-doped ceria (GDC) electrolyte/ nickel-GDC anode system
}

\author{
Yoshihiro HIRATA, ${ }^{\dagger}$ Kenshi MATSUMOTO, Soichiro SAMESHIMA, Naoki MATSUNAGA, \\ Minako NAGAMORI and Taro SHIMONOSONO*
}

Department of Chemistry, Biotechnology, and Chemical Engineering, Kagoshima University, 1-21-40 Korimoto, Kagoshima 890-0065

*Fine Particle Processing Group, Nano Ceramics Center, National Institute for Materials Science, 1-2-1 Sengen, Tsukuba, Ibaraki 305-0047

Cell performance was measured at 773-1073 K for Ni-GDC(Gd-doped ceria) anode-supported GDC film (60 $\mu$ m thickness) with $\mathrm{SrRuO}_{3}$ cathode using a 3 vol\% $\mathrm{H}_{2} \mathrm{O}$-containing $\mathrm{H}_{2}$ fuel. Reduction of particle size $(<1 \mu \mathrm{m})$ of $\mathrm{SrRuO}_{3}$ cathode was effective to decrease the voltage drop at the cathode because of the increased length of triple phase boundary (GDC electrolyte$\mathrm{SrRuO}_{3}$ cathode- $\mathrm{O}_{2}$ gas). Open circuit voltage $(\mathrm{OCV})$ of GDC electrolyte in an anode atmosphere without $\mathrm{H}_{2}$ fuel was close to the value calculated by Nernst equation for no electronic conduction. However, the OCV in a $\mathrm{H}_{2}$-containing atmosphere decreased from the values by Nernst equation owing to the increased electronic conduction in a GDC film. This tendency of decrease in $\mathrm{OCV}$ became significant for thinner GDC film. This result was interpreted by the dissolution and dissociation of

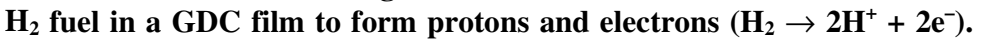

(2009 The Ceramic Society of Japan. All rights reserved.

Key-words : Gadolinium-doped ceria, Solid oxide fuel cell, Open circuit voltage, Hydrogen, Electric power

[Received June 8, 2009; Accepted July 16, 2009]

\section{Introduction}

Solid oxide fuel cell (SOFC) at intermediate temperatures $(773-1073 \mathrm{~K})$ has been intensively studied to increase the lifetime of SOFC and to expand the choice of the constituent materials used for electrodes and interconnector. The effective strategy for the intermediate temperature SOFC is (1) development of electrolyte of high oxide ion conductivity, (2) processing of thin electrolyte film, ${ }^{1)}$ and (3) decrease of overpotential of electrochemical reactions at electrodes (especially cathode) $.^{2)} \mathrm{Sc}-$ stabilized zirconia ( $\mathrm{ScSZ}$ ), $\mathrm{La}-\mathrm{Sr}-\mathrm{Ga}-\mathrm{Mg}-\mathrm{O}$ perovskite structure solid solution electrolyte $\left(\mathrm{La}_{0.8} \mathrm{Sr}_{0.2} \mathrm{Ga}_{0.8} \mathrm{Mg}_{0.2} \mathrm{O}_{3}\right.$, LSGM), and rare earth-doped ceria (RDC) are possible attractive electrolytes. For these electrolytes, the following cathodes have been investigated from the points of view of chemical compatibility with electrolyte, electronic conduction and overpotential at cathode: $\mathrm{La}_{1-x} \mathrm{Sr}_{x} \mathrm{CoO}_{3-\delta}$ (LSC), ${ }^{3)} \mathrm{La}_{1-x} \mathrm{Sr}_{x} \mathrm{Co}_{1-y} \mathrm{Fe}_{y} \mathrm{O}_{3-\delta}$ (LSCF), ${ }^{4)}$ $\mathrm{Sm}_{0.5} \mathrm{Sr}_{0.5} \mathrm{CoO}_{3}(\mathrm{SSC})^{5)}$ and $\mathrm{SrRuO}_{3}{ }^{6)}$ Thin electrolyte films with thickness of $10-50 \mu \mathrm{m}$ have been fabricated by slurry coating, ${ }^{7)}$ plasma sputtering, ${ }^{8)}$ chemical vapor deposition (CVD), ${ }^{9)}$ sol-gel method, ${ }^{10)}$ and electrochemical vapor deposition. ${ }^{11)}$

In our previous paper, ${ }^{1)}$ we reported the processing and cell performance of the anode-supported GDC films $(30-100 \mu \mathrm{m}$ thickness) with $\mathrm{SrRuO}_{3}$ cathode. The measured maximum power density was 380 and $100 \mathrm{~mW} / \mathrm{cm}^{2}$ at 1073 and $873 \mathrm{~K}$, respectively. However, the open circuit voltage (OCV) of the cell was low as compared with the values calculated by Nernst equation: $0.74,0.51$ and $0.57 \mathrm{~V}$ for the GDC films of 100,90 and $30 \mu \mathrm{m}$ thickness, respectively, at $1073 \mathrm{~K}$ under $10^{-17} \mathrm{~Pa}$ of anode oxy-

Corresponding author: Y. Hirata; E-mail: hirata@apc.kagoshima-u. ac.jp gen pressure. The decrease of OCV results in the decreased power density and should be analyzed to suggest the improved material design. In previous papers, ${ }^{12), 13)}$ we measured the electronic conductivity of RDC ( $\mathrm{R}=\mathrm{Gd}, \mathrm{Sm}$ and La) using HebbWagner method and reported the structure change in RDC $(\mathrm{R}=$ $\mathrm{Sm}$ and $\mathrm{Nd}$ ) after heating at $973 \mathrm{~K}$ under a low oxygen partial pressure by XRD and XPS. ${ }^{14)}$ In this paper, we report OCV as a function of thickness of GCD electrolyte and analyze OCV by the internal short circuit current of a mixed conductor of oxide ions and electrons. In addition, the influence of cathode structure on the electric power of anode-supported GDC cell is studied. The decreased size of $\mathrm{SrRuO}_{3}$ particles is effective to increase the length of triple phase boundary (GDC electrolyte $-\mathrm{SrRuO}_{3}$ cathode $-\mathrm{O}_{2}$ gas), leading to the increased electric power.

\section{Experimental procedure}

\subsection{Powder preparation of SOFC components}

A GDC powder of $\mathrm{Ce}_{0.8} \mathrm{Gd}_{0.2} \mathrm{O}_{1.9}$ composition was prepared by the pyrolysis of an oxalate solid solution precursor, $\left(\mathrm{Ce}_{0.8} \mathrm{Gd}_{0.2}\right)_{2}\left(\mathrm{C}_{2} \mathrm{O}_{4}\right)_{3}$. A mixed nitrate solution $(0.2 \mathrm{M})$ of $\mathrm{Ce}$ and $\mathrm{Gd}$ was added into a $0.4 \mathrm{M}$ oxalic acid solution. The produced coprecipitate was decomposed to GDC at $873 \mathrm{~K}$. The detailed characteristics of the produced GDC powder are reported in our previous papers. ${ }^{15), 16)}$ The GDC powder was milled with alphaalumina ball for $24 \mathrm{~h}$. This milled powder was used to make GDC electrolyte films and Ni-GDC anode. The milled GDC powder was immersed into a $1.4 \mathrm{M} \mathrm{Ni}\left(\mathrm{NO}_{3}\right)_{2}$ solution to make a cermet anode with a volume ratio of $\mathrm{Ni} / \mathrm{GDC}=40 / 60$. The freeze-dried powder was heated at $873 \mathrm{~K}$ for $4 \mathrm{~h}$ in air to make a NiO-GDC mixed powder. ${ }^{17), 18)}$ On the other hand, a mixed 0.2 $\mathrm{M}$ solution of $\mathrm{RuCl}_{3}$ and $\mathrm{Sr}\left(\mathrm{NO}_{3}\right)_{2}$ with a molar ratio of $\mathrm{Ru} / \mathrm{Sr}=$ $1 / 1$ was added into a $2 \mathrm{M} \mathrm{NH}_{4} \mathrm{OH}$ solution and then freeze-dried 
to form a $\mathrm{SrRuO}_{3}$ cathode powder. The freeze-dried powder was heated at $1073-1273 \mathrm{~K}$ for $2-4 \mathrm{~h}$ in air. ${ }^{6}$ The heated $\mathrm{SrRuO}_{3}$ was milled with alpha-alumina ball ( $3 \mathrm{~mm}$ diameter) for $24 \mathrm{~h}$. The size and phase of milled powder were investigated by X-ray diffraction (RINT 2200, Rigaku Denki Corp., Ltd., Japan) and scanning electron microscope (SM-300, Topcon Corp.).

\subsection{Fabrication of anode-supported SOFC}

GDC suspensions of 15-25 vol\% solids were prepared using a mixed solution of toluene (33 vol\%) and isopropanol (67 vol\%). Polyethyleneglycol of 9 mass $\%$ and polyvinyl butyral of 5 mass\% were added to the non-aqueous GDC suspensions. ${ }^{1)}$ The suspensions were stirred for $24 \mathrm{~h}$ and then consolidated on polyester sheet by doctor blade (DP-100, Tsugawa Seiki Seisakusho, Tokyo) at a transfer rate of $15 \mathrm{~cm} \cdot \mathrm{min}^{-1}$. The front and back blade clearance was 170 and $250 \mu \mathrm{m}$, respectively. The formed film was left at room temperature for $24 \mathrm{~h}$. The dried film was cut and shaped into a circle of $22 \mathrm{~mm}$ diameter. The GDC film was placed on a NiO-GDC powder bed $(22 \mathrm{~mm}$ diameter, $2 \mathrm{~mm}$ thickness) to form a porous structure and copressed uniaxially at $50 \mathrm{MPa}$, followed by isostatic pressing at $294 \mathrm{~Pa}$. The copressed compacts were heated at $1673-1773 \mathrm{~K}$ for $4 \mathrm{~h}$ in air. The bulk density and microstructure of the cosintered laminate were investigated by the Archimedes method using distilled water and scanning electron microscope. The $\mathrm{SrRuO}_{3}$ powders before and after the milling were dispersed, respectively, at 15 vol\% solid in a mixed solution of $90 \mathrm{vol} \%$ ethanol - $10 \mathrm{vol} \%$ ethyleneglycol. This suspension was spread on the GDC electrolyte over NiO-GDC anode by screen printing (mesh $70 \mu \mathrm{m}$, diameter $4 \mathrm{~mm}$ ), and heated at $1173-1273 \mathrm{~K}$ for $1 \mathrm{~h}$ in air. The thickness of the attached layer was $80-100 \mu \mathrm{m}$.

\subsection{Measurement of cell performance}

A Pt wire reference electrode was fixed on the surface of GDC film with Pt paste at $1173 \mathrm{~K}$. A Pt mesh was also attached to the each electrode with Pt paste. The anode-supported GDC cell was set to an alumina holder and sealed at $1173 \mathrm{~K}$ using a glass Oring. The cell performance was measured by feeding air (100 $\left.\mathrm{ml} \cdot \mathrm{min}^{-1}\right)$ and $3 \mathrm{vol} \% \mathrm{H}_{2} \mathrm{O}$-containing $\mathrm{H}_{2}$ fuel $\left(100 \mathrm{ml} \cdot \mathrm{min}^{-1}\right)$ into the cathode and anode, respectively. The $\mathrm{NiO}$ of the anode was reduced to $\mathrm{Ni}$ by heating at $1073 \mathrm{~K}$ in a $\mathrm{H}_{2}$ fuel before the measurement of cell performance $\left(\mathrm{NiO}+\mathrm{H}_{2} \rightarrow \mathrm{Ni}+\mathrm{H}_{2} \mathrm{O}\right) .{ }^{17)} \mathrm{A}$ direct current-voltage relation was measured at 773-1073 K (As-510, NF Kairosekkei Block Co., Japan). The oxygen partial pressure of the fuel was monitored by yttria-stabilized zirconia oxygen gas sensor operated at $973 \mathrm{~K}$. The OCV of the anodesupported GDC cell was compared with OCV values of the cells with thick GDC electrolyte (500 and $700 \mu \mathrm{m}$ thickness) and NiYSZ anode-supported YSZ cell ( $40 \mu \mathrm{m}$ thickness) with Pt cathode. The thick GDC electrolytes were prepared by pressing a raw GDC powder isostatically at $294 \mathrm{MPa}$ into a disk of $22 \mathrm{~mm}$
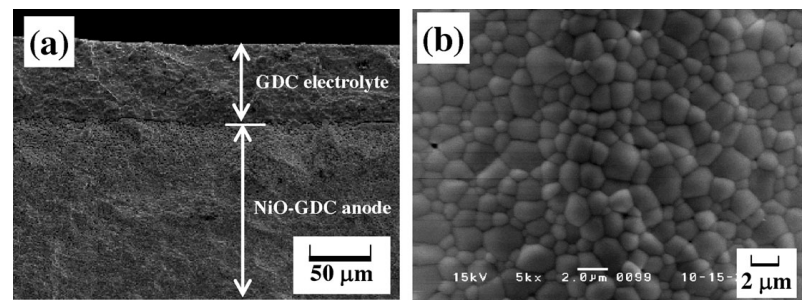

Fig. 1. Cross section (a) and surface (b) of gadolinium-doped ceria (GDC) film supported by NiO-GDC anode. diameter and $2 \mathrm{~mm}$ thickness and by subsequent sintering at $1773 \mathrm{~K}$ for $4 \mathrm{~h}$ in air. The NiO-GDC suspension (anode) and $\mathrm{SuRuO}_{3}$ suspension (cathode) were spread on the polished surfaces of thick GDC electrolyte of $15 \mathrm{~mm}$ diameter. A NiO-YSZ anode-supported YSZ electrolyte was formed by dry pressing and doctor blade processing ${ }^{19)}$ as described in section 2.2. The green cell was sintered at $1623 \mathrm{~K}$ in air. The relative density of NiO-YSZ anode with dense YSZ film was $85.4 \%$. A high purity commercial YSZ powder (13.4 mass $\% \mathrm{Y}_{2} \mathrm{O}_{3}, 86.6$ mass $\% \mathrm{ZrO}_{2}$, TZ-8Y, Tosoh Corp.) was used as a raw powder.

\section{Results and discussion}

\subsection{Microstructures of cell and cathode particles}

Figure 1 shows the cross section and surface structure of dense GDC film (60 $\mu \mathrm{m}$ thickness) supported by NiO-GDC anode after cosintering in air at $1673 \mathrm{~K}$ for $4 \mathrm{~h}$. Little pores were observed on the GDC film and the grain size ranged from 1.0 to $3.7 \mu \mathrm{m}$. The GDC film was tightly adhered to the thick NiOGDC anode. No warp of the laminate (anode-supported GDC film) was observed after the cosintering. In previous paper, ${ }^{1)}$ the following important results and analysis were reported for the sintering of the laminate: (1) the laminate using a thin anode layer warped after the sintering because of the difference in the shrinkage of electrolyte and electrode layers, (2) a higher shrinkage was measured for the electrode at 1373-1473 K and for the electrolyte at 1573-1773 K, and (3) the increase of the thickness of anode was effective to decrease the warp and to increase the bulk density of the laminate. Based on the above understanding, the thickness of green NiO-GDC anode was adjusted to $2 \mathrm{~mm}$ in this paper and as a result no warp was achieved after the sintering.

On the other hand, $\mathrm{SrRuO}_{3}$ cathode has a high electronic conductivity and high chemical compatibility with GDC electrolyte but shows a rapid grain growth during the heating of precursor (mixture of $\mathrm{RuCl}_{3}$ and $\left.\mathrm{Sr}\left(\mathrm{NO}_{3}\right)_{2}\right){ }^{6), 20)}$ The suppression of grain growth of $\mathrm{SrRuO}_{3}$ particles is desired to maintain the effective length of triple phase boundary (GDC electrolyte- $\mathrm{SrRuO}_{3}$ cathode- $\mathrm{O}_{2}$ gas). Figure 2 shows the $\mathrm{SrRuO}_{3}$ particles formed by heating at $1173-1273 \mathrm{~K}(\mathrm{a}, \mathrm{c})$ and by subsequent milling with $\mathrm{Al}_{2} \mathrm{O}_{3}$ ball ( $3 \mathrm{~mm}$ diameter) for $24 \mathrm{~h}(\mathrm{~b}, \mathrm{~d})$. The average particle size was 13 and $19 \mu \mathrm{m}$ for the heating at $1173 \mathrm{~K}$ for $4 \mathrm{~h}$ and 1273
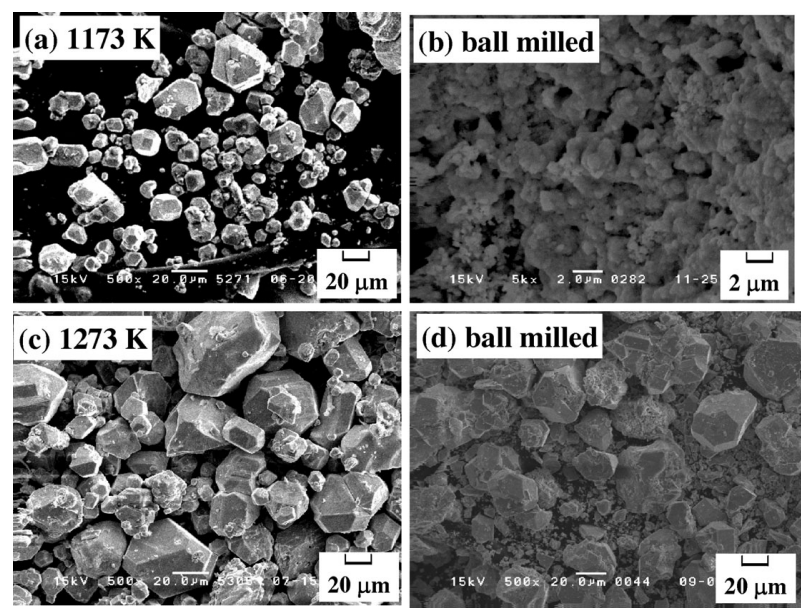

Fig. 2. $\mathrm{SrRuO}_{3}$ cathode particles formed by heating at $1173 \mathrm{~K}$ for $4 \mathrm{~h}$ (a) and $1273 \mathrm{~K}$ for $2 \mathrm{~h}$ (c). The produced particles (a) and (c) were subsequently milled with $\mathrm{Al}_{2} \mathrm{O}_{3}$ ball for $24 \mathrm{~h}$ to form particles (b) and (d), respectively. 
$\mathrm{K}$ for $2 \mathrm{~h}$, respectively. When the $\mathrm{SrRuO}_{3}$ precursor was heated at $1273 \mathrm{~K}$ for $4 \mathrm{~h}$, the particle size increased more to $30 \mu \mathrm{m}$. That is, the size of $\mathrm{SrRuO}_{3}$ is sensitive to the heating condition. After the ball milling, little change was observed for the $\mathrm{SrRuO}_{3}$ formed at $1273 \mathrm{~K}(\mathrm{c}, \mathrm{d})$. However, the average size of particles formed at $1173 \mathrm{~K}$ decreased drastically to $0.9 \mu \mathrm{m}$ by the milling. In this paper, the milled fine $\mathrm{SrRuO}_{3}$ particles were printed on the surface of GDC film. Fortunately, no significant change was observed for the cathode particles after the measurement of cell performance at $773-1073 \mathrm{~K}$.

\subsection{Measurement of cell performance with dense thin GDC film}

The cell performance of $60 \mu \mathrm{m}$ thin GDC film covered with $0.9 \mu \mathrm{m} \mathrm{SrRuO}$ particles (cell 1) was measured using a $\mathrm{H}_{2}-\mathrm{H}_{2} \mathrm{O}$ fuel and compared with the cell performance of $90 \mu \mathrm{m}$ GDC film covered with $19 \mu \mathrm{m} \mathrm{SrRuO}_{3}$ particles (cell 2), reported in our previous paper. ${ }^{1)}$ Figure 3 shows the terminal voltage (a) and electric power density (b) as a function of current density at 773-

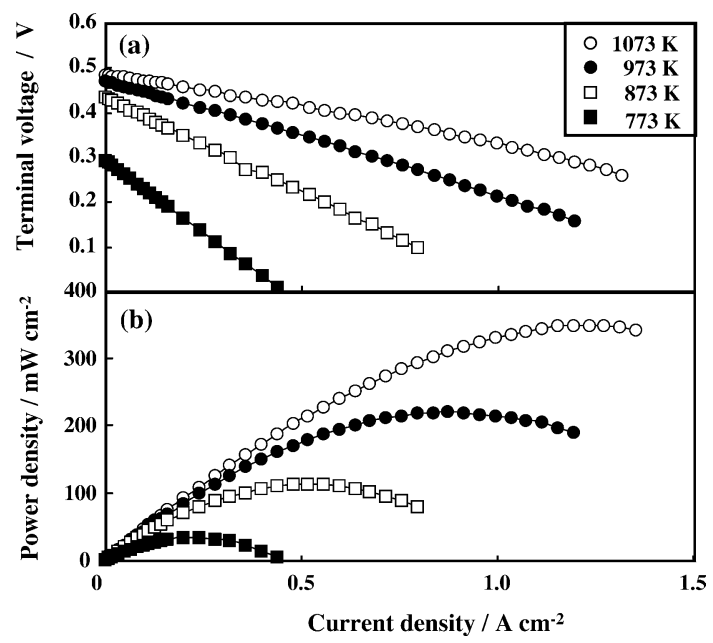

Fig. 3. Terminal voltage (a) and electric power density (b) as a function of current density at $773-1073 \mathrm{~K}$ for anode-supported cell with 60 $\mu \mathrm{m}$ GDC film covered with $0.9 \mu \mathrm{m} \mathrm{SrRuO}_{3}$ cathode particles.

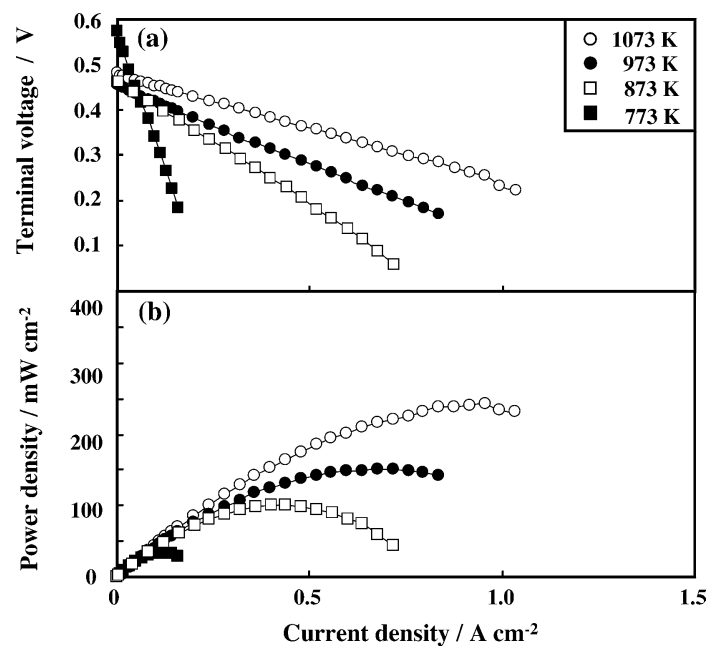

Fig. 4. Terminal voltage (a) and electric power density (b) as a function of current density at 773-1073 K for anode-supported cell with 90 $\mu \mathrm{m}$ GDC film covered with $19 \mu \mathrm{m} \mathrm{SrRuO}_{3}$ cathode particles.
$1073 \mathrm{~K}$ for cell 1 . The OCV was $0.294,0.434,0.471$ and 0.484 $\mathrm{V}$ at $773,873,973$ and $1073 \mathrm{~K}$, respectively. The oxygen partial pressure at the anode was measured to be $2.00 \times 10^{-23}$ and 3.48 $\times 10^{-17} \mathrm{~Pa}$ at 873 and $1073 \mathrm{~K}$, respectively. These values were used to calculate the OCV by Nernst equation. The calculated OCV was 1.17 and $1.11 \mathrm{~V}$ at 873 and $1073 \mathrm{~K}$, respectively. The measured OCV deviated from the calculated OCV. This result is discussed more in a latter part and indicates the increased electronic conduction of the GDC film in the $\mathrm{H}_{2}-\mathrm{H}_{2} \mathrm{O}$ fuel. The maximum power density was 33, 113, 219 and $348 \mathrm{~mW} / \mathrm{cm}^{2}$ at 773 , 873,973 and $1073 \mathrm{~K}$, respectively.

Figure 4 shows the performance of cell 2 . The oxygen partial pressures measured at the anode were similar to those in Fig. 3. The OCV for cell 2 was also lower than that calculated by Nernst equation. The maximum power density was 34, 100, 150 and 244 $\mathrm{mW} / \mathrm{cm}^{2}$ at $773,873,973$ and $1073 \mathrm{~K}$, respectively. The power density between cells 1 and 2 was similar at the low temperatures $(<873 \mathrm{~K})$. However, cell 1 showed a higher power density than cell 2 at the high temperatures (>973 K). This enhanced power density in cell 1 resulted from the decreased thickness of GDC film and the increased length of triple phase boundary at the cathode.

Figure 5 shows the voltage drop between $\mathrm{SrRrO}_{3}$ cathode and reference Pt cathode at $973-1073 \mathrm{~K}$ for cells 1 and 2 . The voltage drop became apparently smaller for cell 1 than for cell 2 . The reduction of particle size $(<1 \mu \mathrm{m})$ of $\mathrm{SrRuO}_{3}$ cathode was effective to increase the length of triple phase boundary. As a result, overpotential at the cathode was reduced. The higher operation temperature decreases efficiently the voltage drop at the cathode because of the higher reaction rate between electrons and oxygen molecules at the cathode.

An interesting measurement in cell 1 was the decrease of OCV with time as shown in Fig. 6. Basically, no oxide ions are transported in a solid electrolyte with no electronic conduction at 0

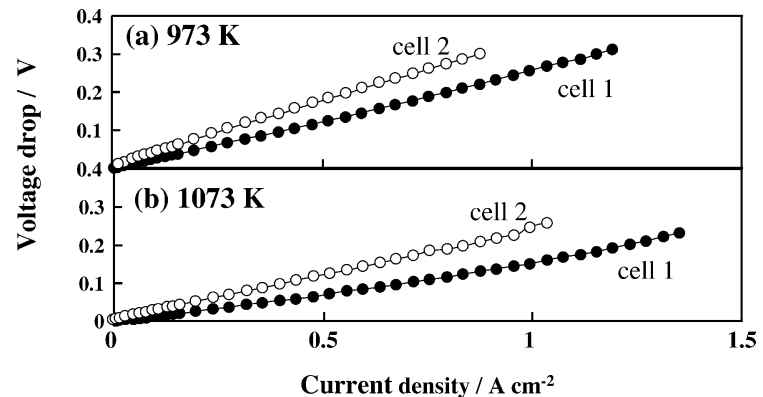

Fig. 5. Voltage drop between $\mathrm{SrRuO}_{3}$ cathode and reference Pt electrode at (a) 973 and (b) $1073 \mathrm{~K}$ for cell 1 with $0.9 \mu \mathrm{m} \mathrm{SrRuO}_{3}$ cathode particles and cell 2 with $19 \mu \mathrm{m} \mathrm{SrRuO}_{3}$ cathode particles.

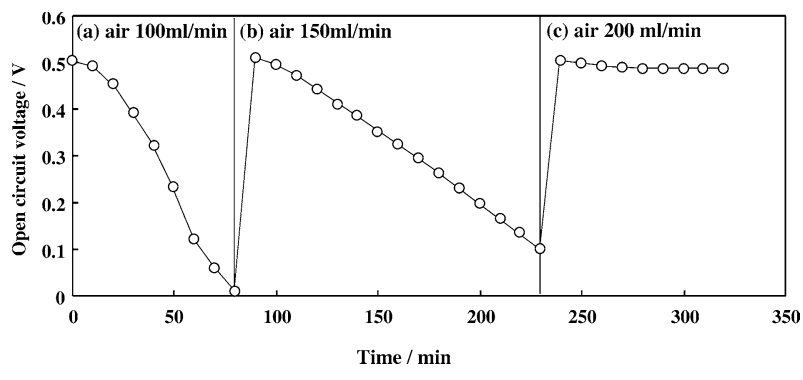

Fig. 6. Open circuit voltage (OCV) of cell 1 with $60 \mu \mathrm{m}$ GDC film covered with $0.9 \mu \mathrm{m} \mathrm{SrRuO}_{3}$ cathode particles as a function of flow rate of air. 
$\mathrm{A} / \mathrm{cm}^{2}$ of current density. That is, the OCV of electrolyte with unity of transference number of oxide ions is independent of the flow rate of air. This discussion is carried out in section 3.3. The decrease of $\mathrm{OCV}$ is related to the decrease of oxygen partial pressure in the cathode layer, as presented by Eq. (5) or (6) in a latter part. The GDC film is a mixed conductor of oxide ions and electrons at a given oxygen pressure of anode. Under the OCV condition, the current densities of oxide ions and electrons are same in the magnitude as shown in Fig. 7. The oxygen molecules in the cathode layer are transported as oxide ions to the anode side through GDC layer. The electrons produced at the anode move to the cathode side. This transport phenomena proceed under the OCV condition. When the rate of supply of oxygen molecules into the cathode layer is smaller than the flow rate of air, the oxygen partial pressure inside of the cathode layer decreases as compared with the oxygen partial pressure of air, causing the decrease of OCV. The fine $\mathrm{SrRuO}_{3}$ particles $(<1 \mu \mathrm{m})$ were used to make the cathode in cell 1 . The decreased particle size leads to the formation of hierarchical structure of small pores in the cathode layer. ${ }^{21)}$ This makes the difficultly of diffusion of air into the cathode layer. As seen in Fig. 6, the OCV was independent of the measurement time as the flow rate of air was increased. On the other hand, the OCV of cell 2 using the cathode with large $\mathrm{SrRuO}_{3}$ particles $(19 \mu \mathrm{m})$ was stable at the small flow rate $(100 \mathrm{ml} / \mathrm{min})$ of air. This result is due to the formation of large open spaces in the cathode layer. The smooth migration of air and fuel inside the electrode layers provides the stable OCV. A similar transport mechanism of oxygen molecules was measured in the thermal decomposition of ammonia over nickel/ Gd-doped ceria cermet which separated ammonia gas from air. ${ }^{22)}$ Although the pyrolysis of ammonia proceeded over a dense GDC electrolyte, no $\mathrm{H}_{2}$ was detected in the outlet gas. This result was explained by the formation of $\mathrm{H}_{2} \mathrm{O}$ from $\mathrm{H}_{2}$ and $\mathrm{O}_{2}$ transported through a GDC mixed conductor from air.

\subsection{Open circuit voltage and internal short circuit current}

Figure 7 shows the flux $(\mathrm{J})$ of $\mathrm{O}^{2-}$ ions and electrons in a mixed conductor with thickness $\mathrm{L}$ facing both air and fuel of a low oxygen pressure $\mathrm{Po}_{2}(\mathrm{a})$. The $\mathrm{J}\left(\mathrm{O}^{2-}\right)$ is derived in a previous paper $^{22)}$ and presented by Eq. (1),

$$
\mathrm{J}\left(\mathrm{O}^{2-}\right)=\frac{\sigma\left(\mathrm{O}^{2-}\right)}{2 \mathrm{~F}}\left[\frac{1}{2} \mathrm{RT} \frac{\partial \ln \mathrm{Po}_{2}}{\partial x}+2 \frac{\partial \eta(\mathrm{e})}{\partial x}\right]
$$

where $\sigma\left(\mathrm{O}^{2-}\right)$ is the conductivity of oxide ions, $\mathrm{R}$ the gas constant, $\mathrm{F}$ the Faraday constant, $\mathrm{T}$ the temperature, and $\eta$ the electrochemical potential of electron. The $\mathrm{J}(\mathrm{e})$ is represented by Eq. (2),

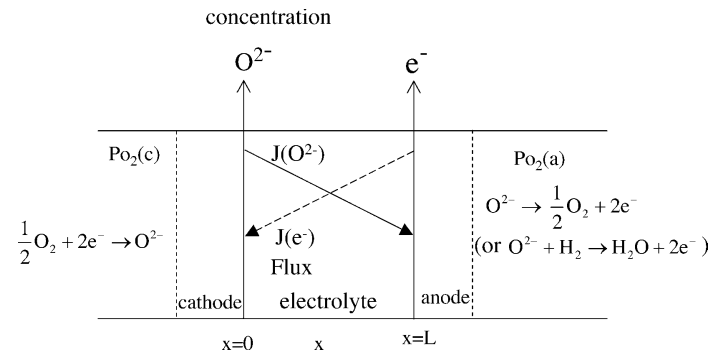

Fig. 7. Flux (J) of $\mathrm{O}^{2-}$ ions and electrons in a mixed conductor with thickness $\mathrm{L}$ facing both air (cathode) and fuel (anode).

$$
\mathrm{J}(\mathrm{e})=\frac{\sigma(\mathrm{e})}{\mathrm{F}} \frac{\partial \eta}{\partial x}=-\sigma(\mathrm{e}) \frac{\partial \varphi}{\partial x}
$$

where $\varphi$ is the electric potential. The electronic conductivity $\sigma$ (e) is expressed by Eq. (3),

$$
\sigma(\mathrm{e})=\mathrm{K} \mathrm{Po}_{2}{ }^{-1 / \mathrm{n}}
$$

where $\mathrm{K}$ and $\mathrm{n}$ are constants. Under an open circuit, the summation of $\mathrm{J}\left(\mathrm{O}^{2-}\right)$ and $\mathrm{J}(\mathrm{e})$ is 0 . This condition leads to an internal short circuit current by Eq. (4) and open circuit voltage (E) by Eq. (5).

$$
\begin{aligned}
& \left|\mathrm{J}\left(\mathrm{O}^{2-}\right)\right|=|\mathrm{J}(\mathrm{e})|=\frac{\mathrm{nRT}}{4 \mathrm{FL}} \sigma\left(\mathrm{O}^{2-}\right) \ln \left[\frac{\sigma\left(\mathrm{O}^{2-}\right)+\mathrm{KPo}_{2}(\mathrm{c})^{-1 / \mathrm{n}}}{\sigma\left(\mathrm{O}^{2-}\right)+\mathrm{KPo}_{2}(\mathrm{a})^{-1 / \mathrm{n}}}\right] \\
& \mathrm{E}=\varphi(\mathrm{c})-\varphi(\mathrm{a})=\frac{\mathrm{nRT}}{4 \mathrm{~F}} \ln \left[\frac{\mathrm{Po}_{2}(\mathrm{c})^{1 / \mathrm{n}}+\left\{\mathrm{K} / \sigma\left(\mathrm{O}^{2-}\right)\right\}}{\mathrm{Po}_{2}(\mathrm{a})^{1 / \mathrm{n}}+\left\{\mathrm{K} / \sigma\left(\mathrm{O}^{2-}\right)\right\}}\right]
\end{aligned}
$$

When a mixed conductor has no electronic conduction $(\mathrm{K}=0)$, $\mathrm{J}\left(\mathrm{O}^{2-}\right)$ and $\mathrm{J}(\mathrm{e})$ become zero, indicating no transportation of oxide ions and electrons. The open circuit voltage for $\mathrm{K}=0$ is given by Eq. (6) as known as Nernst equation.

$$
\mathrm{E}_{\mathrm{N}}(\mathrm{K}=0)=\frac{\mathrm{RT}}{4 \mathrm{~F}} \ln \left(\frac{\mathrm{Po}_{2}(\mathrm{c})}{\mathrm{Po}_{2}(\mathrm{a})}\right)
$$

From Eqs. (4), (5) and (6), OCV of a mixed conductor is related to the internal short circuit current $\left(\mathrm{J}=\left|\mathrm{J}\left(\mathrm{O}^{2-}\right)\right|=|\mathrm{J}(\mathrm{e})|\right)$ by Eq. (7). This equation is convenient to estimate $J$ value when $K$ and $\mathrm{n}$ values of electronic conductivity (Eq. (3)) are not measured.

$$
\mathrm{E}=\mathrm{E}_{\mathrm{N}}-\left(\frac{\mathrm{L}}{\sigma\left(\mathrm{O}^{2-}\right)}\right) \mathrm{J}
$$

Figure 8 shows the OCV measured for GDC and YSZ electrolyte at 873 and $1073 \mathrm{~K}$ as a function of oxygen partial pressure at the anode. The dotted lines express $\mathrm{E}_{\mathrm{N}}$ by Eq. (6). The solid lines represent Eq. (5) for GDC electrolyte, where $\mathrm{n}$ and $\mathrm{K}$ were determined by Hebb-Wagner ion blocking cell in previous papers. ${ }^{12), 13)}$ These solid lines deviated from the Nernst equation at lower $\mathrm{Po}_{2}$ (a) range because of the increased electronic conduction of GDC electrolyte at the anode.

The formation of electrons at the anode side of GDC electrolyte is closely related to the reduction of $\mathrm{Ce}^{4+}$ to $\mathrm{Ce}^{3+}{ }^{12)}$ : $\mathrm{Ce}_{\mathrm{Ce}}^{\times}+\mathrm{O}_{\mathrm{O}}^{\times} \Leftrightarrow \mathrm{Ce}_{\mathrm{Ce}}^{\prime}+\mathrm{V}_{\mathrm{O}}^{\bullet \bullet}+\mathrm{e}^{-}+\frac{1}{2} \mathrm{O}_{2}, \quad 2 \mathrm{Ce}_{\mathrm{Ce}}^{\times}+\mathrm{O}_{\mathrm{O}}^{\times} \Leftrightarrow 2 \mathrm{Ce}_{\mathrm{Ce}}^{\prime}+$ $\mathrm{V}_{\mathrm{O}}^{\bullet \bullet}+\frac{1}{2} \mathrm{O}_{2}, \mathrm{Ce}_{\mathrm{Ce}}^{\times}+2 \mathrm{O}_{\mathrm{O}}^{\times} \Leftrightarrow \mathrm{Ce}_{\mathrm{Ce}}^{\prime}+2 \mathrm{~V}_{\mathrm{O}}^{\bullet \bullet}+3 \mathrm{e}^{-}+\mathrm{O}_{2}$. The difference of OCV between Eqs. (5) and (6) is due to the above electronic conduction and becomes negligible at a lower temperature (Fig. 8(a)). That is, GDC may be used as an electrolyte of intermediate temperature SOFC. The OCV $(1.08 \mathrm{~V})$ of YSZ at 1073 $\mathrm{K}$ lies on the dotted line by Eq. (6). A slight deviation was observed at $873 \mathrm{~K}$ between Eq. (6) (1.13 V) and OCV (1.05 V) of YSZ. The above result is associated with the significantly high chemical stability of YSZ and the high transference number of oxide ions in a $\mathrm{H}_{2}$-rich atmosphere. As seen in Figs. 3 and 4, the OCV measured for GDC films facing air and $\mathrm{H}_{2}-\mathrm{H}_{2} \mathrm{O}$ fuel deviated from Eq. (5) and showed apparently a tendency of decrease with decreasing thickness of GDC film. The $\mathrm{H}_{2}$ atmosphere reduces the OCV of GDC film as compared with the atmosphere without $\mathrm{H}_{2}$ molecules (Eq. (5), Hebb-Wagner method) at a similar $\mathrm{Po}_{2}(\mathrm{a})$. This result is important for use of GDC film as an electrolyte of SOFC and is discussed more.

Figure 9 shows the J-L relation of Eqs. (4) and (7) for GDC 


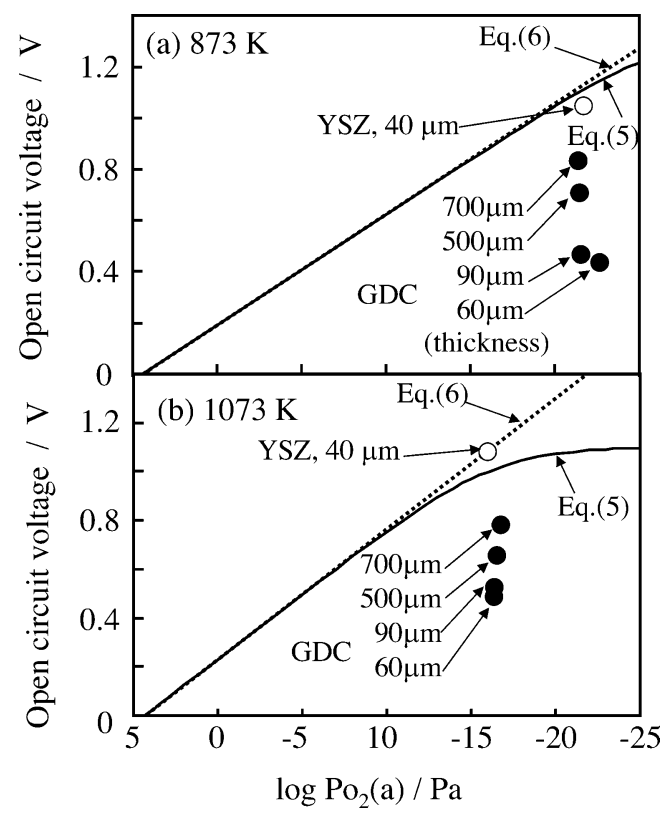

Fig. 8. OCV measured for GDC and YSZ films at 873 (a) and $1073 \mathrm{~K}$ (b) as a function of oxygen partial pressure at anode. The dotted and solid lines represent Eqs. (6) and (5) in text, respectively, and correspond to OCV of GDC without and with electronic conduction in an atmosphere without $\mathrm{H}_{2}$ molecules, respectively.

films. It is found that the internal short circuit current increases as the GDC film becomes thinner. This increased $\mathbf{J}$ causes the decrease in OCV. As seen in Fig. 9, the influence of atmosphere at the anode is significant at a thin GDC film. In the thick GDC electrolyte $(\approx 1 \mathrm{~mm})$, the difference of $\mathrm{J}$ between the two atmospheres with (Eq. (7)) and without $\mathrm{H}_{2}$ fuel (Eq. (4), Hebb-Wagner method) is negligible, suggesting little difference of OCV values. However, the $\mathrm{J}$ value in a $\mathrm{H}_{2}$ fuel (Eq. (7)) is larger than that in a reduced atmosphere without $\mathrm{H}_{2}$ molecules (Eq. (4)) for a thinner GDC film. As seen in Fig. 9, the J value for YSZ film in the $\mathrm{H}_{2}-\mathrm{H}_{2} \mathrm{O}$ atmosphere is very small as compared with the GDC films, supporting the high chemical stability in a $\mathrm{H}_{2}$-rich atmosphere.

\subsection{Influence of $\mathrm{H}_{2}$ at anode}

In previous study, we measured the hydrogen solubility in RDC and YSZ. ${ }^{23)}$ The following solubility of hydrogen was measured by SIMS analyses: $8 \mathrm{~mol} \%$ YSZ $-1 \times 10^{18}$ atom $/ \mathrm{cm}^{3}$ at 1160 $\mathrm{K}, \mathrm{CeO}_{2}-1 \times 10^{18}$ atom/ $/ \mathrm{cm}^{3}$ at $1153 \mathrm{~K}, \mathrm{Ce}_{0.8} \mathrm{La}_{0.2} \mathrm{O}_{1.9}-7 \times 10^{18}$ atom $/ \mathrm{cm}^{3}$ at $1123 \mathrm{~K}, \mathrm{Ce}_{0.8} \mathrm{Yb}_{0.2} \mathrm{O}_{1.9}-1 \times 10^{20}$ atom $/ \mathrm{cm}^{3}$ at 1153 $\mathrm{K}$. RDC has much higher hydrogen solubility than $\mathrm{CeO}_{2}$ or YSZ. When the size of doped rare earth element becomes smaller, the hydrogen solubility increases. This result indicates the oxygen vacancy of RDC may enhance the hydrogen solubility.

The dissolved hydrogen may react with positively charged oxygen vacancy by Eq. (8),

$$
\mathrm{H}_{2}+\mathrm{V}_{\mathrm{O}}^{\bullet \bullet} \rightarrow 2 \mathrm{H}^{+}+\mathrm{V}_{\mathrm{O}}^{\times}
$$

The neutral oxygen vacancy changes to positively charged oxygen vacancy and electrons by Eq. (9).

$$
\mathrm{V}_{\mathrm{O}}^{\times} \rightarrow \mathrm{V}_{\mathrm{O}}^{\ddot{*}}+2 \mathrm{e}^{-}
$$

The summation of Eqs. (8) and (9) provides Eq. (10), which corresponds to the formation of protons and electrons from the dissociated $\mathrm{H}_{2}$ molecules.

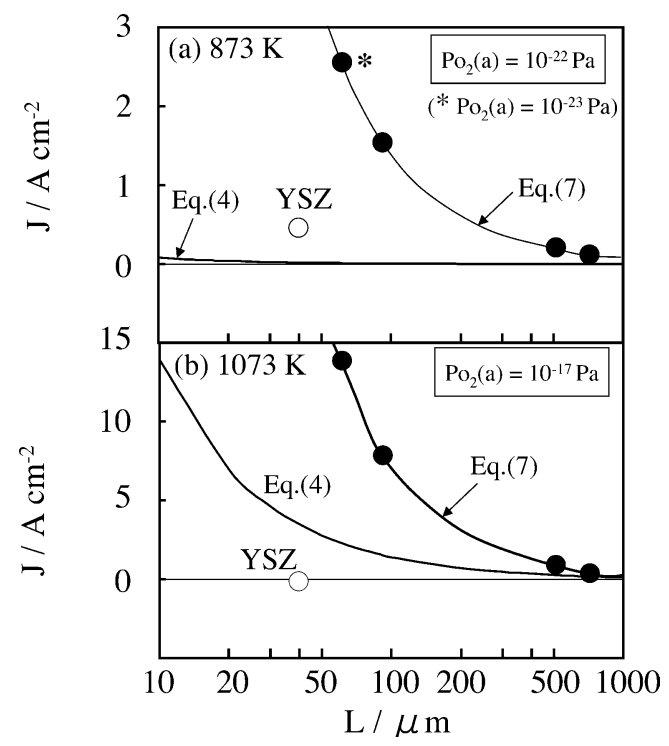

Fig. 9. Relation between thickness (L) of GDC electrolyte and internal short circuit current (J) for the atmospheres without $\mathrm{H}_{2}$ (Eq. (4)) and with $\mathrm{H}_{2}$ (Eq. (7)) at 873 (a) and $1073 \mathrm{~K}$ (b). The L-J relation of YSZ was plotted by putting the measured OCV into Eq. (7).

$$
\mathrm{H}_{2} \rightarrow 2 \mathrm{H}^{+}+2 \mathrm{e}^{-}
$$

As a result, protons and electrons are formed in GDC film, which increases $J$ value in an open circuit (Fig. 9). When the anode atmosphere contains $\mathrm{H}_{2}$ molecules, electrons are produced through two mechanisms: (1) reduction of $\mathrm{Ce}^{4+}$ to $\mathrm{Ce}^{3+}$ as discussed previously, (2) dissociation of $\mathrm{H}_{2}$ molecules by Eq. (10). These two mechanisms may couple to give electron conduction and proton conduction in GDC film: ${ }^{12)}$

$$
\begin{aligned}
& \mathrm{Ce}_{\mathrm{Ce}}^{\times}+\mathrm{O}_{\mathrm{O}}^{\times}+\mathrm{H}_{2} \rightarrow \mathrm{Ce}_{\mathrm{Ce}}^{\prime}+3 \mathrm{e}^{-}+2 \mathrm{H}^{+}+\mathrm{V}_{\mathrm{O}}^{\bullet \bullet}+\frac{1}{2} \mathrm{O}_{2} \\
& \mathrm{Ce}_{\mathrm{Ce}}^{\times}+2 \mathrm{O}_{\mathrm{O}}^{\times}+\mathrm{H}_{2} \rightarrow \mathrm{Ce}_{\mathrm{Ce}}^{\prime}+5 \mathrm{e}^{-}+2 \mathrm{H}^{+}+2 \mathrm{~V}_{\mathrm{O}}^{\bullet \bullet}+\mathrm{O}_{2}
\end{aligned}
$$

The concentration of electrons is greatly increased under the $\mathrm{H}_{2-}$ containing atmosphere as compared with the case without $\mathrm{H}_{2}$ (Fig. 9, Eq. (4)). The important result is the low hydrogen solubility in $\mathrm{CeO}_{2}$ and YSZ, indicating that (1) the interaction between oxygen vacancy in YSZ and hydrogen is small and (2) pure $\mathrm{CeO}_{2}$ without oxygen vacancy by doping of rare earth element has little interaction with hydrogen. This fact concludes that the coupling of the reduction of $\mathrm{Ce}^{4+}$ to $\mathrm{Ce}^{3+}$ and the accompanied formation of oxygen vacancy is responsible for the interaction with $\mathrm{H}_{2}$, producing electron conduction and formation of proton. ${ }^{23)}$ As a result, the OCV is reduced. The prevention of dissolution of hydrogen in a GDC film should be planned to increase the OCV and resultant power density.

The decrease of overpotential at the cathode may be an effective strategy to maintain a high terminal voltage during the operation of SOFC. The overpotential at the anode is usually lower than that of cathode. ${ }^{24), 25)}$ The decrease of overpotential enhances the oxide ion current (flux of oxide ions). When the flux of oxide ions in the GDC film is significantly higher than the flux of hydrogen dissolved, the diffusing oxide ions react with hydrogen molecules at the anode triple phase boundary over the surface of GDC film. This surface reaction is favorable to maintain a high terminal voltage, contributing to a high power density.

Another strategy is the coating of surface (anode side) of GDC 
film with thin YSZ film to prevent the dissolution of $\mathrm{H}_{2}$ fuel. ${ }^{26)}$ The solubility of $\mathrm{H}_{2}$ in YSZ is much lower than that of GDC. In addition the good adhesion of very thin YSZ film suppresses the diffusion of $\mathrm{O}_{2}$ gas formed by the reaction of $\mathrm{Ce}^{4+}$ and lattice $\mathrm{O}^{2-}$ ions in a GDC film at the anode. The above effects contribute to the suppression of formation of electrons and protons and to the resultant increase of OCV or terminal voltage. These effects are studied experimentally in future.

\section{Conclusions}

(1) Reduction of the particle size $(<1 \mu \mathrm{m})$ of $\mathrm{SrRuO}_{3}$ cathode was effective to decrease the voltage drop at the cathode of $\mathrm{Ni}-\mathrm{GDC}$ anode-supported GDC film cell because the length of triple phase boundary at the cathode was increased.

(2) The following maximum power density was measured for the anode-supported cell of $60 \mu \mathrm{m}$ GDC film using a 3 vol\% $\mathrm{H}_{2} \mathrm{O}-\mathrm{H}_{2}$ fuel : $33 \mathrm{~mW} / \mathrm{cm}^{2}$ at $773 \mathrm{~K}, 113 \mathrm{~mW} / \mathrm{cm}^{2}$ at $873 \mathrm{~K}, 219$ $\mathrm{mW} / \mathrm{cm}^{2}$ at $973 \mathrm{~K}$, and $348 \mathrm{~mW} / \mathrm{cm}^{2}$ at $1073 \mathrm{~K}$.

(3) The OCV of thin GDC electrolytes below $1073 \mathrm{~K}$ in the atmosphere without $\mathrm{H}_{2}$ molecules was close to the values calculated by Nernst equation for no electronic conduction by $10^{-15} \mathrm{~Pa}$ of anode oxygen pressure.

(4) However, the OCV of GDC electrolyte in an atmosphere with $\mathrm{H}_{2}$ molecules deviated from the values by the Nernst equation. Hydrogen molecules dissolve greatly in the GDC films to form protons and electrons in the film, leading to the increase in internal short circuit current. This phenomenon causes the decrease in OCV and resultant power density.

(5) The OCV of thin YSZ electrolyte was very close to the theoretical values calculated by Nernst equation. This result is due to the significantly high chemical stability of YSZ in a $\mathrm{H}_{2}$ atmosphere.

(6) Although YSZ contains positively charged oxygen vacancy, the interaction between oxygen vacancy and hydrogen is negligible, leading to the low hydrogen solubility. This result also contributes to the little formation of electrons and protons in YSZ.

\section{References}

1) M. Nagamori, T. Shimonosono, S. Sameshima, Y. Hirata, N. Matsunaga and Y. Sakka, J. Am. Ceram. Soc., 92[S1], S117S121 (2009).

2) Y. J. Leng, S. H. Chan, S. P. Jipang and K. A. Khor, Solid State Ionics, 170, 9-15 (2004).

3) J. Mizusaki, J. Tabuchi, T. Matsuura, S. Yamauchi and K. Fueki, J. Electrochem. Soc., 136, 2082-2088 (1989).

4) J. Lane, P. H. Middleton, H. Fox, B. C. H. Steel and K. Kilner, "Proceedings of Second International Symposium on Ionic and
Mixed Conducting Ceramics," Ed. by T. A. Ramanayanan, W. L. Worrell and H. L. Tuller, The Electrochemical Society Proceeding Series, Pennington, N. J. (1994) pp.489-504.

5) T. Ishihara, M. Honda, T. Shibayama, H. Minami, H. Nishiguchi and Y. Takita, J. Electrochem. Soc., 145, 3177-3183 (1998).

6) T. Shimonosono, G. Hiramatsu, Y. Hirata, S. Sameshima, N. Matsunaga, T. Doi and T. Horita, Adv. Mater. Res., 26-28, 275-278 (2007).

7) S. Sridhar and U. B. Pal, Powd. Tech., 88,173-178 (1996).

8) C. L. Curtis, D. T. Gawne and M. Priestnall, J. Mater. Sci., 29, 3102-3106 (1994).

9) J. Will, A. Mitterdorfer, C. Kleinlogel, D. Perednis and L. J. Gauckler, Solid State Ionics, 131, 79-96 (2000).

10) W. Huang, P. Shuk and M. Greenblatt, Solid State Ionics, 100, 23-27 (1997).

11) H. Sasaki, O. Otoshi, M. Suzuki, T. Sogi, A. Kajimura, N. Sugiura and M. Ippommatsu, Solid State Ionics, 72, 253-256 (1994).

12) T. Shimonosono, Y. Hirata, S. Sameshima and T. Horita, $J$. Am. Ceram. Soc., 88, 2114-2120 (2005).

13) T. Shimonosono, Y. Hirata, Y. Ehira, S. Sameshima and T. Horita, J. Ceram Soc. Japan, Suppl. 112, S616-621 (2004).

14) S. Sameshima, Y. Hirata and Y. Ehira, J. Alloys Comp., 408412, 628-631 (2006).

15) K. Higashi, K. Sonoda, H. Ono, S. Sameshima and Y. Hirata, J. Mater. Res., 14, 957-967 (1999).

16) S. Sameshima, H. Ono, K. Higashi, K. Sonoda and Y. Hirata, J. Ceram. Soc. Japan, 108, 985-988 (2000).

17) Y. Okawa and Y. Hirata, J. Eur. Ceram. Soc., 25, 473480(2005).

18) Y. Okawa, T. Matsumoto, T. Doi and Y. Hirata, J. Mater. Res., 17, 2266-2274 (2002).

19) S. Uchida, S. Sameshima and Y. Hirata, J. Ceram. Soc. Japan, 109,100-105 (2001).

20) T. Shimonosono, Ph. D. Thesis, Department of Advanced Nanostructured Materials Science and Technology, Kagoshima University, 2008.

21) Y. Hirata, I. A. Aksay and R. Kikuchi, J. Ceram. Soc. Japan, 98, 126-135(1990)

22) K. Matsumoto, Y. Hirata, S. Sameshima and N. Matsunaga, J. Ceram. Soc. Japan, 116, 486-490 (2008).

23) N. Sakai, K. Yamaji, T. Horita, H. Yokokawa, Y. Hirata, S. Sameshima, Y. Nigara and J. Mizusaki, Solid State Ionics, 125, 325-331(1999).

24) G. Hiramatsu, Y. Hirata, S. Sameshima and N. Matsunaga, Mater. Sci. Forum, 544-545, 985-988 (2007).

25) Y. Hirata, S. Sameshima and G. Hiramatsu, Proc. $23^{\text {rd }}$ Inter. Korea-Japan Seminar on Ceramics (2006) pp. 93-96.

26) K. Eguchi, T. Setoguchi, T. Inoue and H. Arai, Solid State Ionics, 52, 165-172 (1992). 